deal with problems in a certain area of conflict; statutes setting up agencies may be assumed to focus the solution of the problem in terms of the development of special competence. But a grant of power implies a limit. The simultaneous grant of jurisdiction to the courts or a failure to abolish jurisdiction potentially conflicting may imply such a limit. ${ }^{32}$

If it is conceded that the statutory purpose of uniformity is not substantially furthered by primary jurisdiction, it would seem that the "expertness" argument should not be used as a rationale for disregarding statutory language preserving judicial remedies.

${ }^{32}$ Jaffe, Primary Jurisdiction Reconsidered. The Anti-Trust Laws, 102 U. of Pa. L. Rev. 577 (1954).

\title{
VALIDITY OF CLAUSES PROHIBITING ASSIGNMIENT OF ACCOUNTS AND CONTRACT RIGHTS
}

Without question a contracting party may, by an express provision, prohibit an assignment by an obligor of a contractual duty to provide services or deliver goods. ${ }^{1}$ However, the ability to prohibit an assignment by an obligee of an account or contract right ${ }^{2}$ is less clear. Although a century ago choses in action were not assignable under any circumstances, there is now support for the position that, in some situations, their assignment cannot be prevented. ${ }^{3}$ This latter position has been embodied in the Uniform Commercial Code. ${ }^{4}$

Section 9-318(4) of the Code provides that "[a] term in any contract between an account debtor and an assignor which prohibits assignment of an account or contract right to which they are parties is ineffective." According to the draftsmen, this section is desirable since it makes it always possible for a contracting party to attempt to secure financing through an assignment of his accounts receivable..$^{5}$ Also, it is stated that Section 9-318(4) sets out a rule of law "widely

12 Williston, Contracts $\$ 422$ (Rev. ed., 1936).

2 "'Account' means any right to payment for goods sold or leased or for services rendered which is not evidenced by an instrument or chattel paper. 'Contract right' means any right to payment under a contract not yet earned by performance and not evidenced by an instrument or chattel papers." Uniform Commercial Code §9-106 (Official Edition, 1957).

$3 \pm$ Corbin, Contracts $\$ 873$ (1951).

\$ $\$ 9-318(4)$ (Official Edition, 1957). See also $\$ \$ 2-210(3), 5-116$.

5 " $[\mathrm{A}] \mathrm{s}$ accounts and contract rights have become the collateral which secures an ever increasing number of financing transactions, it has been necessary to reshape the law so that these intangibles, like negotiable instruments and negotiable documents of title, can be freely assigned." Uniform Commercial Code $\$ 9-31 \$(4)$, Comment p. 786 (Official Draft, 1952).

The volume of accounts receivable financing has increased from an estimated $\$ 2$ billion in 1940, Saulnier and Jacoby, Accounts Receivable Financing 4 (1943), and $\$ 4_{2}^{1}$ billion in 1946, Burman, Practical Aspects of Inventory and Receivables Financing, 13 Law \& Contemp. Prob. 555, 556 (1948), to an estimated $\$ 10$ billion in 1956, Kupfer, Accounts Receivable Financing, 2 The Practical Lawyer 50 (1956).

Generally, this type of financing takes one of two forms. Factoring is one arrangement, 
recognized in the cases." Both of these assertions, however, are subject to question.

An examination of the law reveals that the position of the Code is contrary to the weight of authority. ${ }^{7}$ Allhusen v. Caristo Construction Corp., ${ }^{8}$ cited unfavorably by the draftsmen, ${ }^{9}$ sets out the law for the nation's largest commercial state. ${ }^{10}$ There the defendant, a general contractor, subcontracted painting work under an agreement providing that an assignment of any money due or to become due under the contract would be void unless the defendant gave his consent. The subcontractor, without consent, assigned his right to payment to the plaintiff's assignor. The Court of Appeals unanimously affirmed a dismissal of the plaintiff's action to recover payments due for work done by the subcontractor, holding that when the language of the contract clearly invalidates the assignment of any rights thereunder the assignee is barred from recovery against the obligor." Eight other jurisdictions have holdings clearly in accord

whereby a financing institution purchases the accounts outright and assumes all credit risks, the debtors being notified of the assignment. Open accounts receivable financing is the other arrangement whereby the financing institution, on a non-notification basis, either buys the accounts outright or takes an assignment as collateral security. In this latter arrangement the lender usually does not assume any credit risk. For general discussion of the commercial aspects of accounts receivable financing see Guthmann and Dougall, Corporate Financial Policy, cc. 20, 21 (3d ed., 1955); Silbert, Financing and Factoring Accounts Receivable, 30 Harv. Bus. Rev. 39 (1952); Burman, Practical Aspects of Inventory and Receivables Financing, 13 Law \& Contemp. Prob. 555 (1948). For general discussion of the legal aspects see Denonn, Secured Transactions 49-69 (Practising Law Institute, 1955); Kupfer, Accounts Receivable Financing, 2 The Practical Lawyer 50, 55 (1956); Conwill and Ellis, Much Ado About Nothing: The Real Effect of Amended 60(a) On Accounts Receivable Financing, 64 Harv. L. Rev. 62 (1950); Symposium, Secured Commercial Financing, 13 Law \& Contemp. Prob. 553 (1948); Assignments of Accounts Receivable, 1946 Report of the New York Law Revision Commission 351 .

6 Uniform Commercial Code \$ 9-318(4), Comment p. 786 (Official Draft, 1952).

7 The cases examined, infra, do not include those involving insurance policies or contracts for the sale of land, since both of these categories seem to involve unique policy factors. Compare, for example, Murphy v. City of Plattsmouth, 78 Neb. 163, 110 N.W. 749 (1907), with Wagner v. Cheney, $16 \mathrm{Neb} .202,20$ N.W. 222 (1884). For a discussion of the law in regard to insurance contracts see Vance, Insurance $\$ \$ 128,129$ (3d ed., Anderson, 1951); in regard to land contracts see Goodard, Non-Assignment Provisions in Land Contracts, 31 Mich. L. Rev. 1 (1932).

8303 N.Y. 446, 103 N.E.2d 891 (1952).

9 Uniform Commercial Code $\S 9-318(4)$, Comment p. 786 (Official Draft, 1952).

${ }^{10}$ One of the reasons given by the New York Law Revision Commission for refusing to approve the Code was that \$9-318(4) overruled New York law as expressed in the Allhusen decision. Legislative Document No. 65(A), State of New York, Report of the Law Revision Commission to the Legislature Relating to the Uniform Commercial Code 90, 106 (Mimeo., 1956).

11 Although the court had the benefit of amicus briefs by financial institutions, there was no discussion in the opinion of the commercial policy involved. 
with the New York position ${ }^{12}$ and ten more have decisions indicating that they favor it. ${ }^{13}$

Only four jurisdictions have taken a position contrary to that of New York. Two states, Towa ${ }^{14}$ and Pennsylvania, have done so by statute; the latter only by virtue of its enactment of the Uniform Commercial Code. ${ }^{\text {". }}$ Georgia can be added to this group since its Supreme Court in Bewick Lumber Co. $:$. Hall'b held that its statute providing that all choses in action were assignable could not be avoided by contract.

Two courts have held such clauses ineffective without the use of a statute. In State Street Furniture Co. v. Armour \& Co., ${ }^{17}$ the Illinois Supreme Court took the position that, despite a written agreement providing that an assignment of

${ }_{12}$ California: Lelande v. Lowery, 26 Cal.2d 224, 157 P.2d 639 (1945); Fairbanks v. Crump Irrigation and Supply Co., 108 Cal.App. 197, 291 Pac. 629 (1930); cf. Parkinson v. Caldwell, 126 Cal.App.2d 548, 272 P.2d 934 (1954). But cf. Butler v. San Francisco Gas \& Electric Co., 168 Cal. 32, 141 Pac. 818 (1914). Cannecticul: Lewin and Sons, Inc. v. Herman, 143 Conn. 146, 120 A.2d 423 (1956). Massaclucselts: Federal Nat. Bank v. Commonwealth, 282 Mass. 442, 185 N.E. 9 (1933); Old Colony Crushed Stone Co. v. Cronin, 276 Mass. 221, 176 N.E. 804 (1931). But cf. Staples v. City of Sommerville, 176 Mass. 237, 57 N.E. 380 (1900). Nebraska: Murphy v. City of Plattsmouth, 78 Neb. 163, 110 N.W. 749 (1907); City of Omaha v. Standard Oil Co., 55 Neb. 337,75 N.W. 859 (1898). North Caralina: Bank of Northhampton v. Town of Jackson, 214 N.C. 582, 200 S.E. 414 (1939). Tennessee: Standard Acc. Ins. Co. v. Huddleston, 51 F. Supp. 645 (M.D. Tenn., 1943). Texas: Mass. Bonding \& Ins. Co. v. City of Grapeland, 148 S.W.2d 1006 (Tex. Civ. App., 1941); Globe Indemnity Co. v. West Texas Lumber Co., 34 S.IV.2d 896 (Tex. Civ. App., 1930); cf. Reef v. Mills Novelty Co., 126 Tex. 380 , 89 S.W.2d 210 (1936). Wasitington: Indemnity Ins. Co. of North America v. Nelson, 173 Wash. 294, 22 P.2d 984 (1933).

${ }^{13}$ Cf.: Alabumu: Tabler, Crudup \& Co. v. Sheffield Land, Iron \& Coal Co., 79 Ala. 377 (1885); Missotmi: State v. Kent, 98 1Io.App. 281, 71 S.W. 1066 (1903); Olio: United States Life Ins. Co. v. Hessberg, 27 Ohio St. 393 (1875); Oklahoma: Barringer v. Bes Line Construction Co., 23 Okla. 131, 99 Pac. 775 (1909); West Viryinia: White v. Raleigh Wyoming Mining Co., 113 W.Va. 522, 168 S.E. 798 (1933).

Semble: Colorado: School Dist. No. 3 v. Central Savings Bank, 113 Colo. 487,159 P.2d 36 (1945); .IJarylund: In re Bresnan, 45 F.2d 193 (D. Md., 1930); New Jersey: Lehigh Valley Coal Sales Co. v. Apter, 127 N.J. Eq. 125, 11 A.2d 77 (1940); Turner v. Wells, 64 N.J. L. 269, 45 Atl. 641 (1900); Burnett v. Jersey City, 31 N.J. Eq. 341 (1879).

See: District of Columbia: Meyer v. Washington Times Co., 76 F.2d 988 (App. D.C., 1934); Maryland: Andrew v. Meyerdirck, $87 \mathrm{Md}$. 511 , 40 Atl. 173 (1898); Wisconsin: Joint School Dist. No. 2 v. Marathon County Bank, 187 Wis. 416, 204 N.W. 471 (1925).

is "When by the terms of an instrument its assignment is prohibited, an assignment thereof shall nevertheless be valid, but the maker may avail himself of any defense or counterclaim against the assignee which he may have against any assignor thereof before notice of such assignment is given to him in writing." Iowa Code (1954) \$ 539.2. See Instruments Containing Restrictions on Assignment under Iowa Code Section 539.2, 33 Iowa L. Rev. 114 (1947).

${ }^{16}$ Session Laws of Pennsylvania (1953) Vol. 1, pp. 1-182. Prior case law in this jurisdiction had upheld prohibitory clauses. Insley v. State Mut. Life Assur. Co., $334 \mathrm{~Pa} .368,5$ A.2d 544 (1939); Concrete Form Co. v. W. T. Grange Construction Co., 320 Pa. 205, 181 Atl. 589 (1935).

10 94 Ga. 539, 21 S.E. 154 (1894).

${ }^{17} 345$ IIl. 160, 177 N.E. 702 (1931); cf. Bell \& Howell Co. v. Spoor, 225 Ill.App. 256 (1922). Contra: Sperry \& Hutchinson Co. v. Siegel, Cooper \& Co., 309 Ill. 193, 140 N.E. 864 (1923); Mueller v. Northwestern University, 195 Ill. 236, 63 N.E. 110 (1902). 
wages due or to become due without the consent of the employer would be void, an assignment to the plaintiff, who took with notice of the agreement, was valid. The court reasoned that the right to wages was a property right, the alienation of which could not be restricted. In Portuguese-American Bank v. Welles, ${ }^{18}$ followed by the Illinois court, the United States Supreme Court said:

Of course a covenantor is not to be held beyond his undertaking and he may make that as narrow as he likes. ... But when he has incurred a debt, which is property in the hands of the creditor, it is a different thing to say that as between the creditor and a third person the debtor can restrain his alienation of that, although he could not forbid the sale or pledge of other chattels. ${ }^{19}$

However, under Erie R. Co. v. Tompkins ${ }^{20}$ this decision is no longer controlling. And, in any event, Portuguese-American is not strong authority for the position that express prohibitory clauses are ineffective. Since the obligor was not objecting to the assignment, that case may simply stand for the proposition that the clause can only be enforced by the contracting party. ${ }^{21}$ Other cases permitting assignments in spite of clauses are readily distinguishable on the ground that the prohibitory language used was not sufficiently explicit. ${ }^{22}$

At one time an assignment of receivables was considered a confession of financial weakness and an indication that insolvency was imminent. In such a situation it was felt that there was a danger of multiple assignments with competing claims resulting in legal expense to the obligor. Cases upholding prohibitory clauses may reflect this feeling, coupled with a lack of awareness of the present day importance of accounts receivable financing. But an examination of the cases gives little insight into the reasoning of the courts. The decisions appear simply to express the adverse policies of freedom of contract and freedom of alienation. However, these general policies are so abstract that they tend to obscure the underlying reasons supporting and opposing unrestricted assignability of accounts receivable. For purposes of evaluation a deeper analysis is required.

${ }^{18} 242$ U.S. 7 (1916).

${ }^{19} \mathrm{Id}$., at 11.

20304 U.S. 64 (1938). $\quad 214$ Corbin, Contracts $\S 873$ (1951).

${ }^{22}$ Dickson v. City of St. Paul, 97 Minn. 258, 106 N.W. 1053 (1906); Lowry- v. City of Duluth, 94 Minn. 95, 101 N.W. 1059 (1905); Herrick v. Edwards, 106 Mo.App. 633, 81 S.W. 466 (1904); Board of Trustees v. Whalen, 17 Mont. 1, 41 Pac. 849 (1895); Dixon-Reo Co. v. Horton Motor Co., 49 N.D. 304, 191 N.W. 780 (1922).

In Allhusen, the court said: "But these decisions are not to be read as meaning that there can be no enforcible contractual prohibition against the assignment of a claim; indeed, they are authority only for the proposition that, in the absence of language clearly indicating that a contractual right thereunder shall be non-assignable, a prohibitory clause will be interpreted as a personal covenant not to assign.... One would have to do violence to the language here employed to hold that it is merely an agreement by the subcontractor not to assign. The objectivity of the language precludes such a construction. We are therefore compelied to conclude that this prohibitory clause is a valid and effective restriction of the right to assign." Allhusen v. Caristo Const. Corp., 303 N.Y. 446, 450, 452, 103 N.E.2d 891, 892, 893 (1952). 
The tremendous increase in this type of financing in recent years ${ }^{23}$ not only reflects the decline of the above-mentioned commercial stigma but also indicates that such financing fulfills an important economic need. With the rising price level and expanding nature of the economy a greater accumulation of funds is necessary to maintain inventories, finance production, and extend trade or consumer credit. The failure to obtain these funds results in inability to expand production and reach new markets as well as higher costs resulting from the necessity of foregoing trade discounts. ${ }^{24}$ An assignment of accounts is a way out of these difficulties for the large number of concerns which cannot obtain an unsecured line of credit, possess no other suitable collateral, and find equity financing impracticable. To the account creditor these accounts represent a fund of current assets in permanent disuse; to lenders they represent selfliquidating security. Even the firm that can raise capital in another way may find advantages in accounts receivable financing. Instead of accumulating idle funds to pay off a fixed-period loan, each account collected immediately reduces the amount upon which interest is charged. Also, the assignor can profit from the resources for credit investigation and the business counsel of an experienced finance company.

Under the cases and the Code the obligor has a certain degree of protection: he is relieved by payment to an assignor made without notice of the assignment, ${ }^{25}$ and all defenses or claims good against the assignor, arising out of the original contract or accruing before notice of the assignment, are enforceable against the assignee. ${ }^{26}$ The Code goes further in providing that all "reasonable commercial" modifications of executory contracts are binding on the assignee even if made after the obligor has notice of the assignment. ${ }^{27}$ Since contracts

${ }^{23}$ See note 5 supra.

24 "When the seller offers a 30- or 60-day credit term, he is also likely to offer a discount for cash. This cash discount is ordinarily allowed if payment is made within some short period, such as five or ten days. . . . For the number of days that the goods are actually available for sale within the discount period, the buyer may be said to enjoy trade credit without cost. Such terms as the foregoing might be expressed as ' $2 / 10, \mathrm{n} / 30$,' which means that the buyer mar either deduct 2 per cent if he makes payment within ten days after the date of the invoice or pay the net amount shown on the invoice at the end of the 30-day credit period.

"The cost of trade credit is measured by the cash discount. Under the terms just stated, the buyer is paying 2 per cent for an extra 20 days of credit if he fails to discount his bill and takes the full term allowed. If the terms were $2 / 10, \mathrm{n} / 60$, the cost would be 2 per cent for 50 days. But 2 per cent for 20 days is at the rate of 36 per cent for 360 days, and 2 per cent for 50 day's is at the annual rate of 14.4 per cent. In general, computation will show that neglected cash discounts amount to a high annual rate of interest, which suggests the reason why bank credit is used where possible to permit the taking of cash discounts." Guthmann and Dougall, Corporate Financial Policy 441 (3d ed., 1955).

${ }^{25} 4$ Corbin, Contracts $\$ 902$ (1951); 2 Williston, Contracts $\$ \S 433,435$ (Rev. ed., 1936), and cases cited therein. Uniform Commercial Code $\$ 9-318(3)$ (Official Edition, 1957).

${ }^{26} 4$ Corbin, Contracts $\$ \S 895-97$ (1951); 2 Williston, Contracts $\S 433$ (Rev. ed., 1936), and cases cited therein. Uniform Commercial Code $\$ 9-318(1)$ (Official Edition, 1957).

${ }^{27}$ Uniform Commercial Code \$9-318(2) (Official Edition, 1957). 
often have to be altered to fit unforeseen circumstances, this provision does away with what might have been a reasonable basis for the use of prohibitory clauses.

Similarly, the Code draftsmen have avoided another problem which might have been raised by Section 9-318(4). In the case of large corporations with numerous departments, notification of an assignment may be received in one department and transmitted through others before it reaches the bookkeeper. If in the interim the account is paid, it may well have been paid with notice. ${ }^{28}$ While the assignee can legally recover this money from the assignor, ${ }^{29}$ if the latter becomes insolvent or refuses to pay, the obligor corporation will have to pay twice. Since such corporations have large numbers of accounts outstanding this problem could be a serious one. However, under Section 1-201(27) of the Code $^{30}$ notice would not be effective until it reached the department making payment. While such a provision would impose a burden on an assignee, he is in a position to compensate for this by "holdbacks" or higher rates.

The Code, however, does not deal effectively with the problem of set-off rights. If an obligor has a number of contracts with the same party and the latter assigns the accounts under any of them, the obligor is prevented after notice from setting-off against such assignments any subsequent claims arising under the unassigned contracts. ${ }^{31}$ Although this problem is limited to those instances where the damages arising under the unassigned contracts exceed the obligation owed, such instances can be numerous-for example, damages for breach of warranty may exceed the purchase price or the assignor may become liable for liquidated damages under the contract. ${ }^{32}$ While an obligor assumes the risk of being unable to recover such claims due to the insolvency of the obligee, he should not be forced to assume the additional risk of losing set-off rights because of assignments.

A further argument for the validity of prohibitory clauses rests on the necessity of determining whether or not an assignment is valid before the obligor can safely pay the assignee. In the case of a large business this process involves the examination of hundreds of assignments governed by the laws of many jurisdictions. This examination adds greatly to the obligor's costs and, although such costs could sometimes be passed on to the consumer, it would seem that a debtor should be able to avoid this difficulty if he so desires.

The Code draftsmen appear to take the position that the need for unin-

${ }^{28}$ Mechem, Outlines of Agency $\$ \S 494-96$ (3d ed., 1923), and cases cited therein.

${ }^{29} 4$ Corbin, Contracts $\$ 873$ (1951); 2 Williston, Contracts $\$ 422$ (Rev, ed., 1936).

${ }_{30}$ "Notice, knowledge or a notice or notification received by an organization is effective for a particular transaction from the time when it is brought to the attention of the individual conducting that transaction, and in any event from the time when it would have been brought to his attention if the organization had exercised due diligence." Uniform Commercial Code §1-201(27) (Official Edition, 1957).

3 See note 26 supra.

32 E.g., Krauss v. Greenbarg, 137 F. 2d 569 (C.A. 3d, 1943). 
hibited accounts receivable financing overcomes these arguments. But it does not necessarily follow that the validity of prohibitory clauses spells disaster for such financing. While it is possible that the tremendous growth of this type of financing in recent years would have been even greater if prohibitory clauses were ineffective, an alternative explanation is that the use of such clauses is not widespread and that even where they are employed there is incentive for their waiver in appropriate cases. ${ }^{33}$ Since sellers desiring accounts receivable financing may hesitate to deal with buyers using such clauses, a buyer will presumably insist on their use only when he feels them essential. And, when the situation is such that the seller is able to pass on to the obligor the added costs engendered by prohibitory clauses, there is additional incentive for their waiver. Thus, even if one accepts the draftsmen's position that business needs can impose restriction on bargaining power, unless it can be demonstrated that accounts receivable financing is now being significantly restricted, the Code provision, eliminating the useful functions of these clauses, appears undesirable.

${ }^{33}$ One writer, who favors $\$ 9-318(4)$, has stated: "Be it said to the credit of such concerns that, in many instances, they are willing either to waive or modify the restrictions where their suppliers are responsible people." Kupfer, Accounts Receivable Financing, 2 The Practical Lawyer 50, 65 (1956). 